"Water-related sustainability reporting practices amongst South African mining and non-mining corporations"

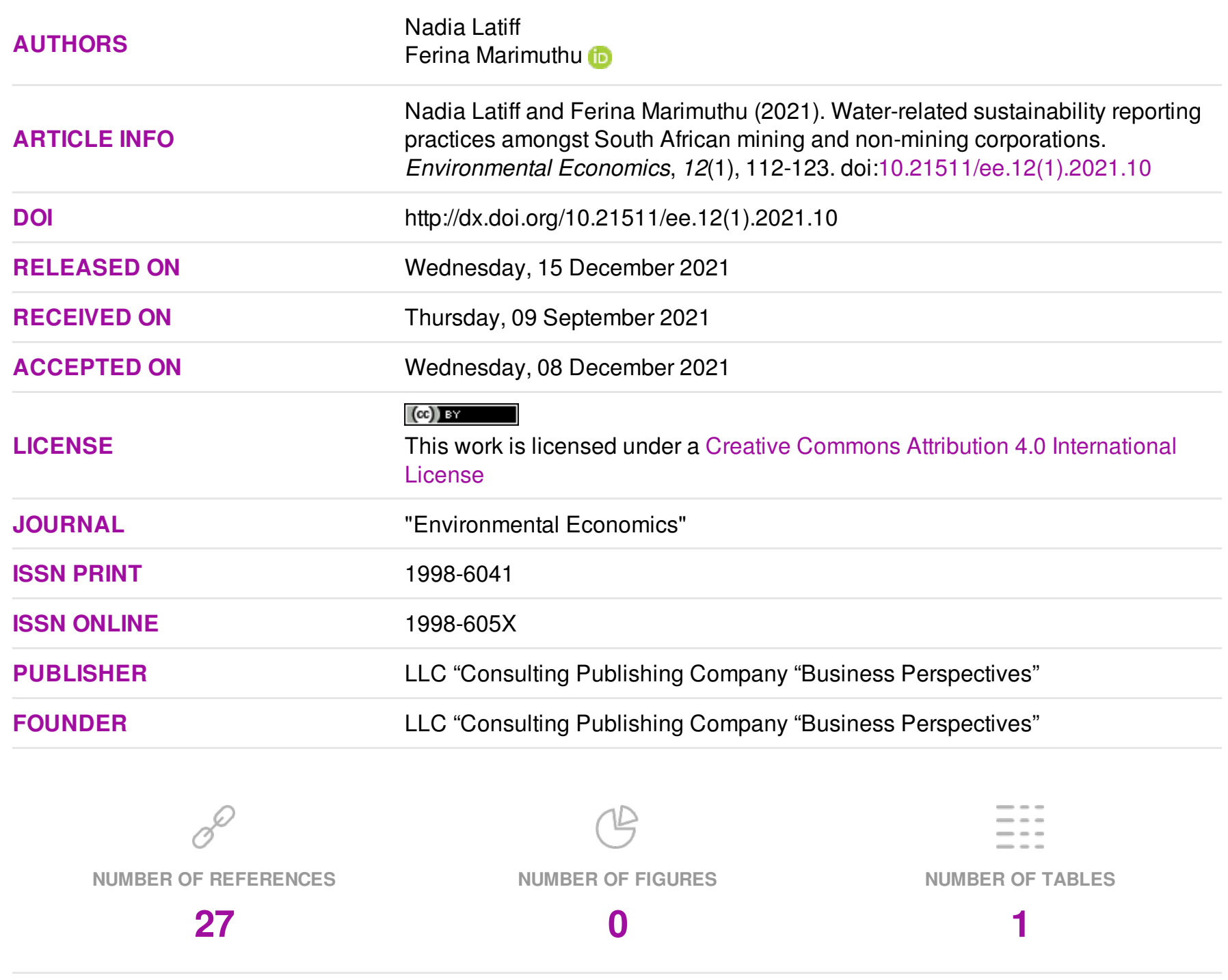

(C) The author(s) 2022. This publication is an open access article. 


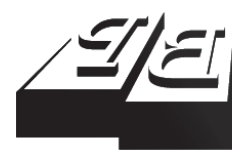

\section{BUSINESS PERSPECTIVES}

()

LLC "CPC "Business Perspectives" Hryhorii Skovoroda lane, 10, Sumy, 40022, Ukraine www.businessperspectives.org
Received on: $9^{\text {th }}$ of September, 2021 Accepted on: $8^{\text {th }}$ of December, 2021 Published on: $15^{\text {th }}$ of December, 2021

(c) Nadia Latiff, Ferina Marimuthu, 2021

Nadia Latiff, MCom, Lecturer, Faculty of Management Sciences, Department of Accounting and Law, Mangosuthu University of Technology, South Africa.

Ferina Marimuthu, Ph.D., Head of Department, Senior Lecturer, Department of Financial Accounting Durban University of Technology, South Africa. (Corresponding author)

\title{
WATER-RELATED \\ SUSTAINABILITY REPORTING PRACTICES AMONGST SOUTH AFRICAN MINING AND NON- MINING CORPORATIONS
}

\begin{abstract}
Globally, water resource management has emerged as an important research area and is acknowledged as a crucial factor in achieving sustainable development goals. Despite its significance, water-related sustainability disclosures regarding water and water-related risks among companies are alarmingly weak. Many companies are not effectively measuring, managing, and disclosing their water-related risks. Hence, this paper aims to analyze water-related reporting and disclosure requirements of a sample of ten South African mining and non-mining companies with a high water profile, listed on the JSE Socially Responsible Investment Index. The companies' level of compliance on water disclosure was assessed based on their reporting in the integrated and or annual reports. The findings revealed that sampled five mining companies performed poorly in terms of disclosure across the frameworks of awareness, disclosure, management, and leadership. On the other hand, the selection of five non-mining companies grasped the severe effect of the water crisis on their businesses and performed better in all the framework categories. The average score for the selection of mining companies was $65 \%$ compared to the $93 \%$ for the non-mining companies. Stakeholders need to focus on water governance processes that require improvement to enable the stakeholders to make better decisions on water management; subsequently, this is an area that needs to be addressed in future research.
\end{abstract}

\section{Keywords}

JEL Classification

\section{INTRODUCTION}

South Africa is currently experiencing a water crisis associated with the quality of water available and in general - water availability. The quantum of water required for food production is immense (Blaine, 2013). Furthermore, it is a prerequisite for producing energy and is vital in producing agricultural chemicals and fertilizers, crop growth, rearing cattle, and retrieving marine food. Water is also required throughout the value chain to process, package, transport, store, and dispose the food (Von Bormann \& Gulati, 2014).

King and Lessidrenska (2009) highlighted that water has become the scarcest and most coveted resource around the globe. Therefore, companies must recognize the value of water and commit to preserving water shortage. Barton (2010, p. 7) believes that many industries would cease to perform and operate without water. Even though water is crucial to business, many companies have not recognized water as an asset. Barton (2010, p. 7) also highlighted that water shortage is an epidemic that organizations should consider and thus provide more 
information to investors. Given the imminent water scarcity, investors require increased information on water sustainability disclosures to minimize the risk on their investments (Ayoola \& Olasanmi, 2013).

In the past, the reporting of company performance involved mainly financial information, which painted a narrow picture of company overall performance (Ayoola \& Olasanmi, 2013). A significant drawback of this reporting was that it failed to paint a picture of what the future holds and could not address issues that the $21^{\text {st }}$ century has plagued $(\mathrm{PwC}, 2013)$. In addition, little information on how a company will mitigate its negative aspects and enhance its positive aspect was provided (SAICA, 2010).

Baird (2012) posited that investors have become more aware that water scarcity poses a risk to the profitability of their investments and are seeking more corporate water disclosure. Given this fact, the Sustainability Accounting Standards Board (SASB) was launched to bridge the gap between investors' needs for additional disclosure and the lack of non-financial information that existing accounting standards assure to provide sustainability standards pertinent to each industry (SASB, 2012).

Given the bleak possibility of no or scarce water available for businesses, companies must understand that water scarcity poses a threat to some business models. This is because it will change raw materials, production methods, and investor demands. Thus, the company's responsibility is to provide information to stakeholders (Baird, 2012). The effects of the impending global water crisis could harm the future of business. Many companies are not effectively measuring and managing their water-related risks, hence the significance of this study is to analyze water-related reporting and disclosure requirements of companies deemed high water consumers.

\section{LITERATURE REVIEW}

Many South African core economic activities are situated in locations where limited water is available. A decline in water quality arising from acid mining drainage adds stress to the existing water situation. In addition, the country is faced with issues such as deteriorating infrastructure, poor municipal management, and water-shedding issues (Askham, 2016). Thus, it is vital for companies to be aware and equipped to respond to these risks that could affect their operations.

South Africa suffers from water scarcity as $98 \%$ of this resource has already been allocated (CDP, 2014). It has also been included in one of the 30 most water-stressed countries globally (Botha, 2015). The situation is exacerbated with low annual rainfall and a minimal source of underground aquifers (CDP, 2014). Projections are that by 2030 there will be a $17 \%$ shortfall between the demands of water and its supply. Quantitatively, this is estimated at roughly a water shortfall of 2.7 billion $\mathrm{m}^{3}$ (CDP, 2012).

Given the very high levels of water scarcity that the country is experiencing and the growing de- mand for agricultural and energy production that requires a large amount of water, the existing balance will be challenged (Von Bormann \& Gulati, 2014). Energy and food require a continuous water supply; however, this valuable resource can become the limiting factor. The constant changes in rainfall patterns and the specters of climate variability may create further issues, especially for susceptible farmers who need constant supply for survival. The risks are further aggravated due to changing consumption patterns and demographic pressures (Von Bormann \& Gulati, 2014).

South Africa is world-renowned and ranks third globally in terms of its biodiversity. However, the country has recently been mapped amongst the National Freshwater Ecosystem Priority Areas because $23 \%$ of river ecosystems and $48 \%$ of wetlands are critically endangered (Amis \& Nel, 2011). Yet even though the statistics paint a bleak future for accessing and securing water for the future, many South Africans have taken water for granted.

Three-quarters of South Africans are privileged to open their taps and receive good quality water (WWF, 2013). A high volume of water is wasted annually due to poor management and embed- 
ded water within the food that is not consumed. Approximately 1.6 million $\mathrm{m}^{3}$ of water is obtained from the underground to produce food that is thrown away. In simpler terms, on average, twenty percent of water withdrawals are being utilized to produce food that is never consumed (Von Borman \& Gulati, 2014).

The declining water quality that affects food production for domestic consumption and the agricultural export markets is another concerning issue (Amis \& Nel, 2011). Many threats face water when it leaves the headwaters of the river basin, posing a significant risk to the availability of fresh water in South Africa's long-term agenda (WWFSA, 2015).

Agricultural fertilizers, wastewater that is incorrectly treated, as well as industrial waste are examples of threats to the freshwater supply in South Africa (WWFSA, 2015). A perfect example of the effects of declining water quality can already be seen in the Western Cape region (Von Bormann \& Gulati, 2014). The Western Cape region currently accounts for a quarter of the national agricultural sector's revenue. Further to this, it contributes to more than half of the exported produce of South Africa. The area is home to an estimate of 23,000 ha of irrigated land, which generates a farmgate amount of up to R 1.3 billion. Furthermore, three-quarters of the crop produced is intended for the United Kingdom and Europe. During the export season of 2005, the agricultural sector lost its ability to sell to the overseas market because of water contamination. There were findings of a vast amount of microbial pollution, nutrient enrichment, and salinity in the Berg River. This contamination meant that the Western Cape region no longer meets the microbial standard of the European Union. Major markets planned on canceling the importation of food, which translated into a potential loss of up to R570 million. The Western Cape government has since placed corrective action to remedy the situation and remove the likelihood of this happening again in the catchment area (Von Bormann \& Gulati, 2014).

The effects of water scarcity are far-reaching and have dire consequences (Sappi Nord America, 2015). Water supports life both in the community and ecosystems and is the lifeblood for the eco- nomic sector (CDP, 2015). Even though water can be viewed as a renewable resource, which is replenished annually with rainfall, it is also an irreplaceable resource; yet, in some ways, it can be substituted (Amis \& Nel, 2013). With an ever-increasing population, the demand for an adequate and reliable water source is paramount for sustaining both the economy and individuals (SABMiller et al., 2011).

The above factors give a clear indication that water responsibility is also a concern of the business sector. Through the measurement of responsible behavior, can this natural resource be measured? For the future of businesses to become viable and sustainable, and eco-friendly paradigm needs to be manifested wherein a resource productive and minimal waste economy can be built (Swilling \& Annecke, 2012).

Environment and water risks need to be integrated into the business's overall strategy so that key risks are identified, disclosed, and sufficient controls are devised to upkeep the environment's overall health (CDP, 2014).

Companies can accomplish this by becoming partners in sharing water risks, liaising with both government and NGOs to overcome these risks, and playing a role in helping to promote water sustainability (SABMiller et al., 2011). SABMiller, a company that used to produce beer, through its Water Futures Partnership, has identified that the most crucial factor in overcoming the risk associated with water is that single organizations cannot combat deeply embedded causes of water issues and risks alone. A sustained collective action from the government, private sector, and local communities is paramount for the success of any water management actions (SABMiller et al., 2011).

Deloitte (2012) explained that many companies have become overwhelmed by the water crisis, and addressing the issue in isolation will be very challenging. Hence, companies have chosen to handle the water situation jointly. This involves liaising with the community, engaging the help of competitors and NGOs, as well as working with local government so that they may achieve their water-related targets. A selection of companies that have adopted good water practices has been 
identified during the study. These companies have displayed impressive achievements towards water goals. The paper highlights their water journey and uses their example as a motivation or blueprint for other companies to follow.

In the 2015 Annual Financial Statements, Tiger Brands recognized water as one of their key sustainable development priorities. Water has been identified as a critical component that affects the entire supply chain. In response to this crucial risk, the following programs in terms of water management were initiated:

- More accurate usage of water can be achieved through the sub-metering of water usage. This initiative gives more accurate information of which processes can be completed with less water;

- Awareness drivers amongst employees have been implemented so that they are more aware of water usage and the importance of its conservation;

- Those manufacturing sites that have been identified as having the most significant water footprint are subject to stringent water audits, and improvement plans have been devised and implemented;

- Capital budgeting techniques have been undertaken for projects that deliver high energy as well as water savings. Those that are identified as financially viable have been tabled for investment (Tiger Brands, 2015).

Puma has become the first company to introduce the environmental profit and loss account. The purpose of this is to value the impact that a company has on the environment along the entire value chain. As part of the Sustainable Apparel Coalition (SAC), Puma utilizes the Higg Index derived by the SAC, which places a monetary value on a company's environmental impact (Askham, 2016).

In 2009, SABMiller together with GIZ and WWFSA initiated the Water Futures Partnership. This initiative aims to promote the business case amongst the private sector for sustainable management and engagement in water projects. The purpose of the partnership is to assess and mitigate risk and improve water stewardship and governance in selected areas. SAB has reduced its water consumption by $25 \%$ since 2013 to 3.5 liters of water in terms of a liter beer production. In addition, SAB has fostered a partnership with their barley farmers to reduce water usage. This program aims to preserve water by improving irrigation techniques and measuring soil moisture. Another long-term goal is to develop a crop of barley that is drought resistant (SABMiller et al., 2011).

In the Woolworths Good Business Journey report, the company has highlighted its commitment to sustainability, especially water preservation. During 2015, a considerable amount was invested in a rainwater capture system in the Montague Gardens distribution center. This system aims to capture rainwater through a drainage system that is mounted on the roof. The water collected is used for cleaning and further re-used in the flushing of toilets. During the first week of operation, the system collected 75,000 liters of water, thus reducing the need to withdraw from a potable municipal supply (Woolworths Holdings Limited, 2015). Woolworths has also started a new initiative called Farming for the Future. This project promotes an improved way of farming that encourages farmers to grow the crop that is sustainable and in harmony with the environment. This process involves starting with soil as a key element. Healthy soil retains more water, requires less irrigation and fewer chemical treatments. Fewer chemicals added to the soil result in less chemical run-off, which preserves water quality. It contributes to the overall biodiversity of the soil (Woolworths Holdings Limited, 2015).

The study has highlighted that there are companies that are contributing towards water conservation; however, there are challenges that need to be addressed. For example, King III has highlighted that sustainability reporting parameters and benchmarks have not been standardized (IODSA, 2009). This poses difficulty for companies who wish to comply yet do not know various frameworks available. In addition, if different companies use various frameworks available for natural capital, a comparison between companies becomes difficult. In addition, these frameworks do not pro- 
vide a framework for water in particular but rather a framework for natural capital. A more comprehensive water disclosure ethic can be established by implementing a framework for water disclosure for informal company reporting. The CEO of the Carbon Disclosure Project emphasized the dire need for a value-added and systematic approach to water reporting globally (CDP, 2012). The Global Reporting Initiative also supported water reporting by publishing two reporting guidelines specific to water in their G4 guidelines (Yadava \& Sinha, 2016). The International Council on Mining and Metals (ICMM) has stated that these frameworks have created a platform for creating cohesive and consistent water disclosure frameworks; however, they come with distinct limitations (ICMM, 2019). Askham (2016) used the Ceres Aqua Gauge framework to evaluate nine South African mining companies. The findings revealed that these companies displayed good water stewardship by showing transparency and accountability towards their stakeholders. However, the area of water and supply chain management in the mining sector was found to be neglected. Similar results were reported by the CDP's 2013 Water Report and the 2008 Global Study.

Based on the literature review, it is evident that many water-related risks could affect South African companies, especially considering that South Africa is a water-stressed country with companies being the most significant water users (Askham, 2016). Hence, this study aims to evaluate the water disclosure adopted by these firms to ascertain their responsibility and commitment towards water scarcity.

\section{METHODOLOGY}

This study adopted a qualitative approach to determine if and how the selected South African listed companies measure, manage, engage with stakeholders, and disclose water-related risks in an effective and meaningful manner. Secondary data were obtained from the companies' 2015 sustainability and or integrated annual reports downloaded from their websites. The target population comprised companies listed on the JSE Socially Responsible Investment Index (SRI-index) that measures company performance, policies, and reporting concerning the triple bottom line elements and corporate governance (JSE, 2013).

The SRI-index requires companies to report on society, governance, environment, and sustainability concerns. Furthermore, companies are classified from low to high depending on their impact (JSE, 2013). Pertinent to this study is the environmental category. Using purposive sampling, companies categorized as high-risk were selected. Thereafter, the integrated reports were analyzed to identify if the sampled companies have sufficient information to analyze. The final sample consisted of ten (10) companies listed in those sectors deemed high water risk. After analyzing the integrated reports of 10 companies that met the requirements to be evaluated, a fair amount of data was collected to make inferences and substantiate a reliable outcome. Mining was identified as one of those industries having a high water profile (Askham, 2016). Considering that South Africa is synonymous with mining and the attention given to acid mine drainage, mining companies were grouped as one category whilst non-mining companies were grouped into another category. The selected companies included such mining companies: Anglo American; Anglo Ashanti; Kumba Iron-Ore; Harmony Gold; and Royal Bafokeng Platinum; and non-mining companies: Illovo Sugar; Sappi; SAB; Tiger Brands; and Woolworths Holdings.

The companies' level of compliance was assessed based on four categories:

- Awareness - How comprehensively the company views its business activity and its link with water;

- Management - How well a company understands, monitors, and responds to the risks that affect the quality and quantity of water;

Disclosure - How well a company has measured and disclosed their reliance on water and the effect their operations have on water resources;

- Leadership - What levels of management are directly charged with oversight on water management and sustainability. 
Thereafter, the companies' progress was evaluated against the following three stages for each question described under four categories:

- Achieved: There is sufficient evidence that exists to confirm that the criteria stipulated have been achieved. 'Sufficient evidence' indicates detailed descriptions, methods, or procedures of how the objectives in the relevant question had been achieved.

- Partially achieved: Some evidence was provided to indicate that part of the criteria was met. A partial achievement was scored when details on the question did exist, however, they were not adequately described in the integrated report.

- No evidence of achievement: Insufficient evidence is provided in the reports; hence the stipulated criteria could not be confirmed.

Subsequently, a scoring system was applied to the three levels of evaluation: Achieved - 5 points; Partially Achieved - 3 points; Not Achieved - 1 point. Once the scoring was complete, the number of points a company had earned per category was divided by the maximum number that could have been earned. This fraction was then converted to a percentage, after which a grand total was computed.

\section{RESULTS}

Table 1 presents an analysis of each company's disclosure to 4 categories of the framework: awareness, management, disclosure, and leadership.

The results presented in Table 1 are further analyzed and each category of the framework for the mining and non-mining companies is discussed. Under the Awareness category, Harmony Gold has indicated that water is a significant input in the achievement of their business assets; hence, awareness of this resource's importance is crucial. The matter is heightened because the primary area of operations is South Africa, and the country is currently experiencing water shortages. Royal Bafokeng Platinum has indicated that water is a material item in terms of production and opera- tions. As an initial measure, they have adopted a group-wide strategy to engage with employees to create awareness and highlight the importance of water. This is facilitated through meetings, induction training, awareness training, newsletters, and environmental talk topics. This aims to create an environment wherein employees become mindful of the importance of safeguarding the environment, adopting sustainable practices, and realizing that water is a minimal resource. On the other hand, Kumba has not included water and the importance of its management as a material item being a major mining company. A list of material items is provided, however, water does not fall under this category. Description of water and its importance are included minimally under environmental resource management.

Under the Management category, Harmony Gold has adopted a campaign to re-use all water to reduce the demand on existing groundwater. Furthermore, a list of drought mitigation initiatives has been implemented to reduce the inherent risk that faces the company. As a result, the company better managed their water risks, especially those that arise due to unforeseeable events such as drought. Kumba has described its water management as being a project that is mine specific. This means that research is conducted on each mine, and a corrective strategy is devised. This has proved successful because site-specific strategies are formulated and have had positive results. Furthermore, an automated system is in place across all mines to obtain real-time water readings. A major issue identified by the company is that many strategies are delayed in their implementation, resulting in higher permitting and regulatory risk. This is because there are often long delays in receiving integrated water use licenses (IWULs), which means delays in executing many worthwhile projects. This issue is exacerbated in situations like the Kolomela Mine, which is surrounded by pans and wetlands, and hence an IWUL is needed. Sometimes IWULs are difficult to implement, which often could result in the company receiving environmental directives. Constant engagement with authorities is needed. Anglo American has devised a water project journey involving a three-phase process that aims to understand and identify risk firstly. Thereafter, proactive behavior is required for implementing 
Table 1. Water disclosure framework

\begin{tabular}{|c|c|c|c|c|c|c|c|c|c|c|}
\hline \multirow{2}{*}{ Category } & \multicolumn{5}{|c|}{ Mining companies } & \multicolumn{5}{|c|}{ Non-mining companies } \\
\hline & A & B & C & D & E & $\mathbf{F}$ & G & $\mathrm{H}$ & 1 & J \\
\hline \multicolumn{11}{|c|}{ Awareness category } \\
\hline $\begin{array}{l}\text { 1. Has water management been identified as a material } \\
\text { item? }\end{array}$ & 5 & 5 & 1 & 5 & 5 & 5 & 5 & 5 & 5 & 5 \\
\hline $\begin{array}{l}\text { 2. Has water quality and quantity to the business success } \\
\text { been rated or indicated as important? }\end{array}$ & 5 & 5 & 3 & 5 & 5 & 5 & 5 & 5 & 5 & 5 \\
\hline $\begin{array}{l}\text { 3. Has there been an evaluation on whether water quality } \\
\text { and quantity could affect the company's growth strategy? }\end{array}$ & 5 & 5 & 3 & 5 & 5 & 5 & 3 & 5 & 5 & 5 \\
\hline $\begin{array}{l}\text { 4. Are stakeholders factored into the organization's water } \\
\text { risk assessment? }\end{array}$ & 3 & 3 & 1 & 3 & 3 & 5 & 1 & 5 & 5 & 5 \\
\hline TOTAL SCORE & $18 / 20$ & $18 / 20$ & $8 / 20$ & $18 / 20$ & $18 / 20$ & $20 / 20$ & $14 / 20$ & $20 / 20$ & $20 / 20$ & $20 / 20$ \\
\hline PERCENTAGE SCORE & $90 \%$ & $90 \%$ & $40 \%$ & $90 \%$ & $90 \%$ & $100 \%$ & $70 \%$ & $100 \%$ & $100 \%$ & $100 \%$ \\
\hline AVERAGE SCORE & \multicolumn{5}{|c|}{$80 \%$} & \multicolumn{5}{|c|}{$94 \%$} \\
\hline \multicolumn{11}{|c|}{ Management category } \\
\hline $\begin{array}{l}\text { 1. Has a company engaged in creating procedures to assess } \\
\text { water-related risk pertinent to the company? }\end{array}$ & 5 & 5 & 3 & 5 & 1 & 5 & 5 & 5 & 5 & 5 \\
\hline $\begin{array}{l}\text { 2. Is the risk assessment sufficient for the nature of } \\
\text { operation? (Frequency of risk assessment, methods used)? }\end{array}$ & 5 & 5 & 1 & 5 & 1 & 3 & 3 & 5 & 5 & 5 \\
\hline $\begin{array}{l}\text { 3. Has a company adjusted its strategy or business } \\
\text { operations to accommodate the company's level of water } \\
\text { risk? }\end{array}$ & 5 & 3 & 5 & 5 & 1 & 5 & 5 & 5 & 5 & 5 \\
\hline $\begin{array}{l}\text { 4. Does a company have a suitably developed internal water } \\
\text { standard or strategy? }\end{array}$ & 5 & 5 & 3 & 3 & 1 & 5 & 1 & 5 & 5 & 5 \\
\hline $\begin{array}{l}\text { 5. Have any fines or penalties for non-compliance with } \\
\text { water-related regulations been received? }\end{array}$ & 5 & 1 & 1 & 1 & 1 & 1 & 1 & 1 & 1 & 1 \\
\hline $\begin{array}{l}\text { 6. Has there been any indication of what type of risk affects } \\
\text { a company the most? }\end{array}$ & 5 & 5 & 5 & 5 & 1 & 5 & 5 & 5 & 5 & 5 \\
\hline TOTAL SCORE & $30 / 30$ & $24 / 30$ & $18 / 30$ & $24 / 30$ & $6 / 30$ & $24 / 30$ & $20 / 30$ & $26 / 30$ & $26 / 30$ & $26 / 30$ \\
\hline PERCENTAGE SCORE & $100 \%$ & $80 \%$ & $60 \%$ & $80 \%$ & $20 \%$ & $80 \%$ & $67 \%$ & $87 \%$ & $87 \%$ & $87 \%$ \\
\hline AVERAGE SCORE & \multicolumn{5}{|c|}{$68 \%$} & \multicolumn{5}{|c|}{$82 \%$} \\
\hline \multicolumn{11}{|c|}{ Disclosure category } \\
\hline 1. Has a company identified water as a risk? & 5 & 5 & 1 & 5 & 3 & 5 & 5 & 5 & 5 & 5 \\
\hline $\begin{array}{l}\text { 2. Does a company comply with external water standards } \\
\text { such as GRI, The Water Act ( } 36 \text { of 1998), and King III? }\end{array}$ & 1 & 5 & 1 & 5 & 3 & 5 & 5 & 5 & 5 & 5 \\
\hline $\begin{array}{l}\text { 3. Does the current water strategy present an opportunity } \\
\text { to benefit the organization? }\end{array}$ & 3 & 5 & 3 & 5 & 3 & 5 & 5 & 5 & 5 & 5 \\
\hline $\begin{array}{l}\text { 4. Are sufficient details of water discharge, consumption, } \\
\text { and recycled water volumes disclosed? }\end{array}$ & 3 & 5 & 5 & 5 & 3 & 3 & 5 & 5 & 5 & 5 \\
\hline TOTAL SCORE & $12 / 20$ & $20 / 20$ & $10 / 20$ & $20 / 20$ & $12 / 20$ & $18 / 20$ & $20 / 20$ & $20 / 20$ & $20 / 20$ & $20 / 20$ \\
\hline PERCENTAGE SCORE & $60 \%$ & $100 \%$ & $50 \%$ & $100 \%$ & $60 \%$ & $90 \%$ & $100 \%$ & $100 \%$ & $100 \%$ & $100 \%$ \\
\hline AVERAGE SCORE & \multicolumn{5}{|c|}{$74 \%$} & \multicolumn{5}{|c|}{$98 \%$} \\
\hline \multicolumn{11}{|c|}{ Leadership category } \\
\hline $\begin{array}{l}\text { 1. Is a sufficiently senior individual responsible for the } \\
\text { management of water? }\end{array}$ & 1 & 5 & 1 & 1 & 1 & 5 & 3 & 5 & 5 & 5 \\
\hline $\begin{array}{l}\text { 2. Does a company have a water policy that sets out clear } \\
\text { goals and guidelines for action? }\end{array}$ & 5 & 5 & 3 & 3 & 3 & 5 & 5 & 5 & 5 & 5 \\
\hline TOTAL SCORE & $6 / 10$ & $10 / 10$ & $4 / 10$ & $4 / 10$ & $4 / 10$ & $10 / 10$ & $8 / 10$ & $10 / 10$ & $10 / 10$ & $10 / 10$ \\
\hline PERCENTAGE SCORE & $60 \%$ & $100 \%$ & $40 \%$ & $40 \%$ & $40 \%$ & $100 \%$ & $80 \%$ & $100 \%$ & $100 \%$ & $100 \%$ \\
\hline AVERAGE SCORE & \multicolumn{5}{|c|}{$56 \%$} & \multicolumn{5}{|c|}{$96 \%$} \\
\hline OVERALL PERCENTAGE SCORE ACROSS FOUR CATEGORIES & $77.5 \%$ & $67.5 \%$ & $47.5 \%$ & $77.5 \%$ & $52.5 \%$ & $92.5 \%$ & $79.25 \%$ & $96.75 \%$ & $96.75 \%$ & $96.75 \%$ \\
\hline AVERAGE SCORE & \multicolumn{5}{|c|}{$65 \%$} & \multicolumn{5}{|c|}{$93 \%$} \\
\hline
\end{tabular}

Note: Mining companies: A - Anglo American, B - Anglo Ashanti, C - Kumba Iron- Ore, D - Harmony Gold, E - Royal Bafokeng Platinum; Non-mining companies: F - Illovo Sugar, G - Sappi, H - SAB, I - Tiger Brands, J - Woolworths Holding.

targets and strategies to minimize risk and create opportunities. The third stage involves becoming a catalyst for local water solutions and implementing solutions through improved technologies.
Unfortunately, the company did encounter 15 incidents relating to water. These relate to unauthorized water discharges; however, remedial action was put in place. 
Under the Disclosures category, Anglo Gold Ashanti has devised and adopted a group-wide Integrated Environment and Community Policy and a Water Management Standard. These programs detail how the company liaises with the local community, manages the risk associated with natural capital, and works to prevent pollution and manage waste effectively. The Water Management Standard has detailed guidelines on volumes of water used, measures to reduce freshwater abstraction, enhance water quality, and work with the community to educate on water supply, quality, and access. Goals and targets are set, and these are constantly attained. An example of a target set was to ensure the effluent discharge is within the appropriate parameters. This was duly achieved in 2015 where the discharges were within the appropriate limit. Royal Bafokeng Platinum has set out on commissioning the initial phase of a water treatment plant. This enabled four million liters of water to be treated a day, resulting in less reliance on portable water from the Magalies Water. Harmony Gold has indicated that they have a long-term goal of reducing water usage for primary activities to $4.5 \%$ and increasing water recycling usage to $5 \%$. The company aims to achieve this by 2015 and has procedures in place to meet this. One of their measures was conducting a comprehensive geohydrological assessment at the Kalgold mine. The outcome of this assessment was that a water balance revision is required. Technical changes were conducted so that the maximum amount of water could be recovered for re-use.

Under the Leadership Category, Anglo Gold Ashanti has set out a clearly defined set of goals and targets and indicated that the board and executive board are responsible for managing water. Anglo American, Kumba, and Harmony Gold have indicated an action plan; however, it is not specific. Furthermore, it is alarming for the size and nature of operations that so few guidelines and policies can manage their water footprint. A further concern is that 4 out of the 5 companies in the mining sector have failed to allocate water management responsibility to senior personnel. In addition, no indication is given of whom the responsibility of water stewardship is placed with. Royal Bafokeng has separately indicated that the company has experienced significant challenges in reducing its water intensities. Yet, except for the water plant construction, very few goals and guidelines for actions have been communicated. Anglo American indicated that they have a 10-year water strategy, which began in 2010. Significant progress has been made with the company being in the second or third stage of achieving the goals.

Assessing non-mining companies, it was found that under the Awareness category, Tiger Brands has indicated that water is vital for the business's main operation, especially since it forms the key ingredient to many of the products manufactured. The quality of the water is also vital to operations since many of the goods produced are used for human consumption. Sappi has indicated that their production process relies heavily on both quality and quantity of water, and hence the organizational success and continuity depend on water. Illovo Sugar has indicated that a volatile water supply would significantly harm production. In addition, mills and downstream operations require a certain quality of water for operations. If water sustainability is not met, then additional costs to treat the water are required. SAB has identified water sustainability as material to the continuing success of the company. Water quality and quantity are crucial to the business as water is used in beer production. SAB has shown its commitment to raising the standard on water sustainability throughout the supply chain by ensuring that suppliers comply with environmental laws and behave to protect and enhance the environment. The accreditation process is rigid, requiring suppliers to be transparent and go under technical audits.

Under the Management category, Tiger Brands has utilized several tools to identify the water-related risks affecting the company. One such tool is Aquastat. This method is used to collect and analyze information on the use of water in agricultural activities. Agricultural water usage contributes a big part to Tiger Brands' water consumption. The results are then analyzed to determine and project water-related risks pertinent to the company's agricultural activities.

Sappi has identified water as a risk and thus adjusted strategy to ensure this irreplaceable resource is carefully managed. A particular strategy was to alter the current process of paper bleaching. 
The effluent produced in the traditional method has raised particular concern to environmentalists and consumers. However, bleaching is vital for sales as it improves printability. The company has adopted the element-chlorine-free bleaching process, which significantly enhances the effluent quality and makes it reusable in agricultural irrigation.

Woolworths has indicated that water scarcity poses a major risk to the organization, which could negatively affect operations. As a measure, the company has formulated its program, Farming for the Future, which utilizes best practices for farming and irrigation. This method also ensures minimal water waste and better quality of water by improved techniques. In addition, farmers are encouraged to utilize better practices, which bear less stress on the environment. Woolworths has also invested in the WWF's water neutrality program. As a response to water risk, Illovo has devised a company-wide water strategy called the Illovo Water Management Strategy, which includes better water management, setting and achieving water-related goals as well as introducing water-related Key Performance Indicators. This has helped strengthen the company's commitment to better water stewardship.

Risks to SAB are continually evaluated using various tools, e.g. watershed risk assessment and business water risk assessment. Water instability has a major impact on beer production; hence, the company has introduced Water Futures. This program calls for a collective approach to address the issues affecting water sustainability. As a primary measure to achieve their water targets, $\mathrm{SAB}$ has reduced its water consumption by $25 \%$ since 2013 to 3.5 liters of water per liter of beer produced. During the 2014/2015 year, cost savings of USD 117 million were achieved through water and energy-related initiatives.

Under the Disclosure category, Tiger Brands has employed a group research team that undertakes water risk assessments as part of their 3-year annual strategy. In addition, Tiger Brands have reiterated that improved water responsibility and strategy has resulted in an improved brand value and overall cost savings. This has created a positive image (reputational risk) for both internal and external stakeholders. A commendable practice utilized by Sappi was to restructure operations to ensure water sustainability. The plantation is planned so that roads are constructed to prevent erosion and ensure runoff is not directed to rivers. Runoff is managed by utilizing proper harvesting and extraction methods are used. Woolworths has measured water consumption and efficiency in all of its operations. The company's Farming for the Future program has ensured advanced farming practices that ensure higher soil moisture, greater water retention, and fewer chemical absorption.

Illovo has disclosed their water discharge volume and method for each site, and compliance with relevant national laws is adhered to. In addition, the company participates in the CDP Water program. New processes are continually evaluated to ensure that water consumption is reduced and more water is recycled. The current water strategy adopted by SAB presents an advantage for both the company and other businesses. SAB is a founding signatory of the UN CEO Water Mandate. This initiative aims to assist companies to develop, implement, and report sustainable water practices pertinent to their operations. In addition, the Waters Future program dictates goals and strategies for each site of operation, and constant monitoring is undertaken.

Under the Leadership category, Woolworths internally developed project, Farming for the Future, is an industry leader in setting out goals and targets particular to the company's operations. Set out guidelines are stipulated, and performance against these benchmarks is monitored annually.

Both Illovo and Tiger Brands have indicated that water management is tasked to the board, and hence senior management oversees the progress towards better water management. The introduction of KPIs by Illovo suggests that the company has set out goals and guidelines for water management, aiming to reduce the load on their water footprint. SAB has undertaken the Waters Futures Partnership, which requires the top board level to liaise with the community and government to ensure water goals are achieved. This program also sets out a clear goal and guideline for action. 


\section{DISCUSSION}

From the analysis, it can be deduced that most companies have identified water as a material item for businesses. Hence, there is an awareness that water responsibility needs to be factored into the organizational strategies. By studying integrated and related reports of selected companies, it was ascertained that non-mining companies had shown a greater awareness of water than their mining counterparts. The value-added from this is that companies searching for potential guidance in reporting on the water can utilize the non-mining companies' reports. In addition, greater regulatory and stakeholder supervision should be placed on mining companies to ensure that a more rigorous approach to water management is implemented. This is further emphasized because the WWF identified mining as one of those industries having a high water profile.

Mining companies lagged behind non-mining companies by conducting risk assessments that were insufficient for the nature and size of operations. By being labeled as a high water profile company and thus holding a high water risk, operations would give rise to the companies utilizing a large amount of water. In addition, much attention has been placed on acid mine drainage and its harmful effects. There are many problems associated with acid mine drainage. Some of these problems include drinking water contamination and reproduction and growth disruption (Ayoola \& Olasanmi, 2013).

These insufficient risk assessments were proved because only $40 \%$ of the mining companies had devised internal water strategies to address the water risks pertinent to their operations. Nonmining companies have developed internal strategies to address water risk, and many firms have factored stakeholders into water responsibility. In addition, a clear description of the internal water policy detailed descriptions of the water standard or strategies that other companies have created has been discussed. These strategies include giving clear guidelines on meeting their water-related goals and reducing wastage and their plans. Examples of these include Woolworths' Farming for the Future Initiative and SAB's Waters Futures Partnership. This indicates a commitment to water sustainability.

In terms of disclosure, all the companies under review have indicated details of water usage, discharge, and recycled volumes. Non-mining companies all indicated that they comply with some external water standards; however, only $40 \%$ of the mining companies have indicated compliance with external water standards. Examples of external water standards include ISO 14001, King III, The Water Act (36:1998), and Carbon Disclosure Project.

The leadership aspect displayed by non-mining companies is superior to that described by mining companies. All non-mining companies have indicated that water management lies with some senior management members, indicating the importance of this resource. However, only $20 \%$ of the mining companies have suggested that water responsibility lies with senior personnel. In addition, all of the other companies have disclosed clear guidelines and targets to water, yet only $40 \%$ of mining companies have done so.

\section{CONCLUSION AND RECOMMENDATIONS}

Water is an irreplaceable resource that many businesses rely upon. If companies fail to acknowledge the seriousness of the current water situation, they lie susceptible to many water-related risks that could affect their sustainability. The main aim of this study was to evaluate and analyze water-related reporting and disclosure requirements and ascertain if the sampled companies recognize the importance of water especially given the current water crisis, and are effectively managing their water-related risks and opportunities. Investors are constantly seeking more than just financial information in annual reports to ensure their investments remain profitable.

The results highlighted that non-mining companies performed better in terms of disclosure across all four categories of testing. This is a cause of concern because mining companies use a large amount of 
water. In addition, mining companies are responsible for acid mine drainage, which pollute water. By disclosing their water practices, mining companies will be forced to be more accountable to stakeholders. Across both groups, the perception was that many companies chose to disclose fundamental information.

Companies should be encouraged to provide in-depth discussions of the risks and mitigation factors they have identified. In addition, a report by the chairperson of the committee that oversees natural capital reporting should be included. This report should indicate what targets have been set and progress towards achieving those targets. In this way, companies will be motivated to set goals annually and measure how these have been achieved. A further recommendation is that companies utilize the water disclosure framework presented as part of the study, to ensure that their reporting will encompass various issues that will add value to the reporting process. In addition, a more in-depth analysis of water disclosure can be accomplished, and a comparison between companies may be facilitated.

Water has been identified as just one of the six natural capitals mentioned in the integrated report. However, the company's environmental footprint encompasses other natural capital elements. Future research could evaluate how companies affect the environment by measuring how all six natural capital elements are used and managed.

\section{AUTHOR CONTRIBUTIONS}

Conceptualization: Nadia Latiff.

Data curation: Nadia Latiff.

Formal analysis: Nadia Latiff.

Funding acquisition: Nadia Latiff.

Investigation: Nadia Latiff.

Methodology: Nadia Latiff.

Project administration: Nadia Latiff, Ferina Marimuthu.

Validation: Ferina Marimuthu.

Visualization: Nadia Latiff, Ferina Marimuthu.

Writing - original draft: Nadia Latiff, Ferina Marimuthu.

Writing - review \& editing: Ferina Marimuthu.

\section{REFERENCES}

1. Amis, M., \& Nel, D. (2011). Managing water risk: business response to the risk of climate change in South Africa - a synthesis (WWF Report). Cape Town: WWF South Africa.

2. Askham, T. (2016). Water sustainability: measurement, management, engagement, and disclosure of selected waterintensive companies on the Johannesburg Stock Exchange (Master's Thesis). University of South Africa, Pretoria. Retrieved from http://hdl.handle. net/10500/20222

3. Ayoola, T., \& Olasanmi, O. (2013). Business Case for Integrated
Reporting in the Nigerian Oil and Gas Sector. Issues in Social and Environmental Accounting, 7(1), 30-54. https://doi.org/10.22164/ isea.v7i1.74

4. Baird, H. (2012). Water-related issues could threaten business models. Financial Management, 12. Retrieved from https://vlex. co.uk/vid/water-related-issuescould-635270693

5. Barton, B. (2010). Murky waters? Corporate reporting on water risk: a benchmarking study of 100 companies. Boston, MA: Ceres. Retrieved from https://www. waterfootprint.org/media/downloads/Barton_2010.pdf
6. Blaine, S. (2013, April 17). Agriculture is putting South Africa in deep water. Business Live. Retrieved from https://www. businesslive.co.za/archive/201304-17-agriculture-is-putting-sain-deep-water/

7. Botha, M. (2015). An analysis of water-related sustainability disclosure of Socially Responsible Investment-indexed JSE-listed companies (Master's Thesis). North-West University. Retrieved from http://dspace.nwu.ac.za/ bitstream/handle/10394/14254/ Botha_MJ.pdf

8. Carbon Disclosure Project (CDP). (2012). CDP Water disclosure 
South Africa Report 2011. WSP Environment \& Energy South Africa. Retrieved from https:// www.unisdr.org/preventionweb/ files/26220_cdpwaterreportmar2012.pdf

9. Carbon Disclosure Project (CDP). (2014). CDP South Africa Water Report 2014. National Business Initiative. Retrieved from https:// www.nbi.org.za/wp-content/ uploads/2016/06/CDP_SA_WaterReport_2014_final.pdf

10. Carbon Disclosure Project (CDP). (2015). CDP Global Climate Change Report 2015. At the tipping point? CDP Worldwide. Retrieved from https://cdn.cdp. net/cdp-production/cms/reports/ documents/000/000/578/original/ CDP-global-climate-changereport-2015.pdf

11. Deloitte. (2012). Integrated Reporting - Navigating your way to a truly Integrated Report ( $2^{\text {nd }}$ ed.). Johannesburg: Deloitte. Retrieved from https://www.iasplus.com/en/ publications/south-africa/other/ integrated-reporting-edition-2

12. Institute of Directors in South Africa (IODSA). (2009). King Code of Governance for South Africa 2009 (King III). Retrieved from https://ecgi.global/sites/ default/files/codes/documents/ king3.pdf

13. International Council on Mining and Metals (ICMM). (2019). Adapting to Changing Climate: Implications for the Mining and Metals Industry, Climate Change. Retrieved from https://icmm.uat. byng.uk.net/website/publications/ pdfs/climate-change/adapting-toclimate-change

14. Johannesburg Stock Exchange (JSE). (2013). What is the Socially Responsible Investment (SRI) Index? Retrieved from https:// www.jse.co.za/services/indices/ ftsejse-responsible-investmentindex-series

15. King, M., \& Lessidrenska, T. (2009). Transient caretakers: making life on earth sustainable. Johannesburg: Pan Macmillan.

16. PwC. (2013). Natural Capital Accounting. The next big thing in sustainability? Retrieved from https://www.pwc.com/gx/en/audit-services/corporate-reporting/ publications/world-watch/articles/ pdf/pwc-world-watch-naturalcapital-accounting.pdf

17. SABMiller, GIZ \& WWF-UK (2011). Water futures. Addressing shared water challenges through collective action. Retrieved from http://assets.wwf.org.uk/downloads/waterfuturesreportaug2011. pdf

18. Sappi Nord America. (2015). Sappi group Sustainability report 2015. Retrieved from https://cdns3.sappi.com/s3fs-public/2015Sappi-Group-SustainabilityReport.pdf

19. South Africa Institute of Chartered Accountants (SAICA). (2010). World's three parallel crises call for adoption of Integrated Reporting. SAICA Media Release. Retrieved from https://www.saica. co.za/News/NewsArticlesandPressmediareleases/tabid/695/ itemid/2105/pageid/4/catpageid/6/ language/en-US/Default.aspx

20. Sustainability Accounting Standards Board (SASB). (2012). Homepage of SASB. Retrieved from http://www.sasb.org/

21. Swilling, M., \& Annecke, E. (2012). Just Transitions: Explorations of sustainability in an unfair world. Cape Town: UCT Press. Retrieved from https://unu.edu/publications/books/just-transitions-explorations-of-sustainability-in-anunfair-world.html\# overview

22. Tiger Brands. (2015). Integrated Annual Report 2015. Retrieved from https://www.annualreports.com/HostedData/ AnnualReportArchive/t/OTC_ TBLMF_2015.pdf

23. Von Bormann, T., \& Gulati, M. (2014). The Food Energy Water Nexus: understanding South Africa's most urgent sustainability challenge. South Africa: WWF-SA. Retrieved from http://awsassets. wwf.org.za/downloads/wwf_few_ report_3.pdf

24. Woolworths Holdings Limited. (2015). Farming for the future. Retrieved from https://www.wool- worthsholdings.co.za/wp-content/ uploads/2017/12/whl_2015_integrated_report.pdf

25. World Wide Fund (WWF). (2013). Water stewardship: Perspectives on business risks and responses to water challenges. Retrieved from https://wwfint.awsassets. panda.org/downloads/ws_briefing_booklet_lr_spreads.pdf

26. World Wide Fund South Africa (WWFSA). (2015). Integrated Annual Report. Retrieved November 20, 2015, from https:// wwfafrica.awsassets.panda.org/ downloads/wwf_integrated_annual_report_2015_web_new. pdf?15541/WWF-IntegratedAnnual-Report-2015

27. Yadava, R. N., \& Sinha, B. (2016). Scoring Sustainability Reports Using GRI 2011 Guidelines for Assessing Environmental, Economic, and Social Dimensions of Leading Public and Private Indian Companies. Journal of Business Ethics, 138(3), 549-558. Retrieved from http://www.jstor. org/stable/44164182 